\section{Strength and consistency behaviour of replacement of cement with silicate- based geopolymer cement modified soft soil treated with crushed waste glasses for pavement underlain}

Duc BUI VAN - Faculty of Civil Engineering, and Research Group of Geotechnical Engineering, Construction Materials and Sustainability, Hanoi University of Mining and Geology, Vietnam • buivanduc@humg.edu.vn

Kennedy Chibuzor ONYELOWE - Department of Civil Engineering,

Michael Okpara University of Agriculture, Nigeria • konyelowe@mouau.edu.ng

MichaEl ONYIA - Department of Civil Engineering, Faculty of Engineering,

University of Nigeria • michael.onyia@unn.edu.ng

MAN NGUYEN XUAN - Faculty of Civil Engineering, and Research Group of Geotechnical Engineering, Construction Materials and Sustainability, Hanoi University of Mining and Geology, Vietnam

LAM DAO PHUC - Department of Structure-Materials,

Civil Engineering Faculty University of Transport Technology • lamdp@utt.edu.vn

ChIDOZIE IKPA - Department of Civil Engineering, Faculty of Engineering,

Alex Ekwueme Federal University, Ndufu-Alike Ikwo, Ebonyi State, Nigeria

Somjal YUBONCHIT - Professor of Civil Engineering,

Rajamangala University of Technology Isan, Thailand • d5540150@g.sut.ac.th

ADRIAN EBEREMU - Professor of Civil Engineering,

Ahmadu Bello University, Nigeria - aeberemu@gmail.com

Kolawole OSINUBI - Professor of Civil Engineering,

Ahmadu Bello University, Nigeria - kosinubi@yahoo.com

A. Bunyamin SALAHUDEEN - Department of Civil Engineering, Faculty of Engineering,

University of Jos, Nigeria - basalahudeen@gmail.com

AgAPITUs AMADI - Associate Professor of Civil Engineering,

Federal University of Technology, Nigeria - Agapitus.amadi@futminna.edu.ng

Michael MADUABUCHI - Department of Civil Engineering,

Michael Okpara University of Agriculture, Nigeria

JESUBorN OBIMBA-WOGU - Department of Civil Engineering,

Michael Okpara University of Agriculture, Nigeria

IfEANYICHUKWU ONUOHA - Department of Environmental Technology, School of Environmental

Sciences, Federal University of Technology, Nigeria • ifeanyichukwu.onuoha@futo.edu.ng

ZUBAIR SAING - Associate Professor of Civil Engineering

Universitas Muhammadiyah Maluku Utara, Indonesia • zubairsaing@ummu.ac.id

Érkezett: 2020. 01. 23. " Received: 23. 01. 2020. " https://doi.org/10.14382/epitoanyag-jsbcm.2020.31

\section{Abstract}

The effect of quarry dust based geopolymer cement (QDbGPC) and ordinary Portland cement (OPC) replaced in the ratios of 0:0, 0:40, 5:35, 10:30, 15:25, 20:20, 25:15, 30:10, 35:5, and $40: 0 \%$ by weight respectively was investigated. This was carried out under the influence of $4 \%$, $8 \%, 12 \%, 16 \%$ and $20 \%$ by weight crushed waste glasses. This was conducted to study the effect of these materials on the consistency and strength characteristics of representative test soil in the laboratory. Preliminary test on the test soil shows that the soil is expansive, highly plastic with high clay content and classified as an A-7-6 soil group according to AASHTO classification system. It is also classified as poorly graded according to USCS. The treated exercise presented an improvement in the California bearing ratio, compaction and consistency characteristics in a steady and substantial pattern. The increased addition of the proportions of geopolymer cement caused increased values of $\mathrm{CBR}, \mathrm{G}_{\mathrm{s}}$ and decreased values of plasticity index. The unsuitable and problematic soft soil was improved to meet the requirements for a soil material to be used as a subgrade construction material. This is due to the composite blend of materials with high silicate contents responsible for strength gain. However, the replacement of ordinary Portland cement with silicate-based geopolymer cement will remove the dangers of $\mathrm{CO}_{2}$ emission during construction works and present an environmentally friendly practice of soil re-engineering. Keywords: California bearing ratio, compaction, silicate-based materials, crushed waste glasses, geopolymer cement, recycled solid waste materials, composite construction materials Kulcsszavak: kaliforniai teherbírási érték, tömörítés, szilikát alapú anyagok, zúzott üveghulladék, geopolimer cement, újrahasznosított szilárd hulladékok, kompozit építôanyagok
Duc BUI VAN

Member, Research Group

of Geotechnical Engineering, HUMG. Vietnam

Kennedy Chibuzor ONYELOWE

Senior Lecturer, MOUAU \& AE-FUNAI, Nigeria

Michael ONYIA Senior Lecturer, UNN, Nigeria

Man NGUYEN XUAN

Member, Research Group of Geotechnical Engineering, HUMG, Vietnam

Lam DAO PHUC Researcher, Structure-Materials, UTT, Vietnam

Chidozie IKPA Technologist, AE-FUNAl, Nigeria

Somjai YUBONCHIT Professor, RUTI, Thailand

Adrian EBEREMU

Professor, ABU, Nigeria

Kolawole OSINUB

Professor, ABU, Nigeria

A. Bunyamin SALAHUDEEN

Lecturer, UNIJOS, Nigeria

Agapitus AMAD Professor, FUTMinna, Nigeria

Michael MADUABUCH

Graduate, MOUAU, Nigeria

Jesuborn OBIMBA-WOGU GA, MOUAU, Nigeria

Ifeanyichukwu ONUOHA Lecturer, FUTO, Nigeria

Zubair SAING Associate Professor, UMMU, Indonesia 


\section{Introduction}

The improvement of the mechanical properties of soft soils has become increasingly necessary because of the role soils play in pavement constructions, more especially the underlain foundation structures [1-2]. Pavements are underlain structurally by soils borrowed or compacted in situ, during the foundation phase of flexible or rigid pavements [3-6]. Pavement facilities are important horizontal structures that contribute to the socioeconomic development and environmental accessibility of suburbs, urban centres, cities and nations. Unfortunately, in Nigeria and many other developing countries of the world, the failure rate of pavements is alarming [7]. Over 80 percent of the road pavements in Nigeria are in deplorable state due to primarily badly formed underlain. Worst in this category is located in the south-eastern and southern geopolitical regions of the country [8-9]. Pavement failures are initiated primarily by lateral deformation, which eventually initiate cracks like as presented in Figs. 1 \& 2 [2, 10]. These cracks give way for moisture migration to the underlain structure of the pavements. Further intake of moisture under hydraulically bound conditions causes the underlain subgrade to experience volume changes due swell-shrink cycles [11-12]. According to Herve et al. [1], these volume changes initiate greater degree of failure by shear and lateral heaving. This is the consequence of building pavements with weak and unstable underlain subgrade soils [1,13-17]. The use of ordinary Portland cement in the weak soil stabilization protocols, on the other hand, generates strengthened structures prone to crack effects because of the brittle nature of ordinary cement stabilized soils [18]. Moreover, the use of ordinary Portland cement releases an equivalent amount of $\mathrm{CO}_{2}$ into the atmosphere contributing to global warming and this is at a time when our planet is at the brink of environmental issues as a result of constant exposure to nonenvironmentally friendly construction procedures and practices [19-23]. The synthesis of geopolymer cement with quarry dust as the base material and its utilization in the improvement of the soft soil properties is currently being studied [23-29]. Soil conservation takes many methods and forms depending on its usage and various environmental reasons. This has proven as a sure way of conserving the soils for use as engineering material. However, new and other areas are also being explored to achieve soil stabilization with zero release of $\mathrm{CO}_{2}$ into the environment [30-35]. Crushed waste glasses, also, are eco-friendly geomaterials derived from crushing waste glasses disposed by Glass Industries as scrap losses from glass production or poor handling $[1,36]$. Waste glasses are also solid waste disposed by factories, homes and offices resulting from poor handling, accidents, etc. The utilization of ordinary Portland cement (OPC) and quarry dust based geopolymer cement (QDbGPC or GPC) in this work in a linear inverse replacement pattern was to determine the best geoengineering practices through which silicate-based or bio-based cements can partially or totally replace Portland cements, which inadvertently allow room for the disposal of the solid waste under consideration without exposing the environment or landfills to potential dangers [37-39]. This was conducted in that order to determine the replace-ability of the silicate-based geopolymer cement over ordinary Portland cement [2]. Also, the effect of introducing crushed waste glasses in an incremental order into the cemented test soil was also studied. It was a complex blending of various eco-friendly materials with a view to improving the California bearing ratio, consistency and compaction characteristics of the treated soft soil. According to Herve et al. [1] and Onyelowe et al. [36] the best practices of soil conservation could take this pattern for soils to be used as pavements underlain.

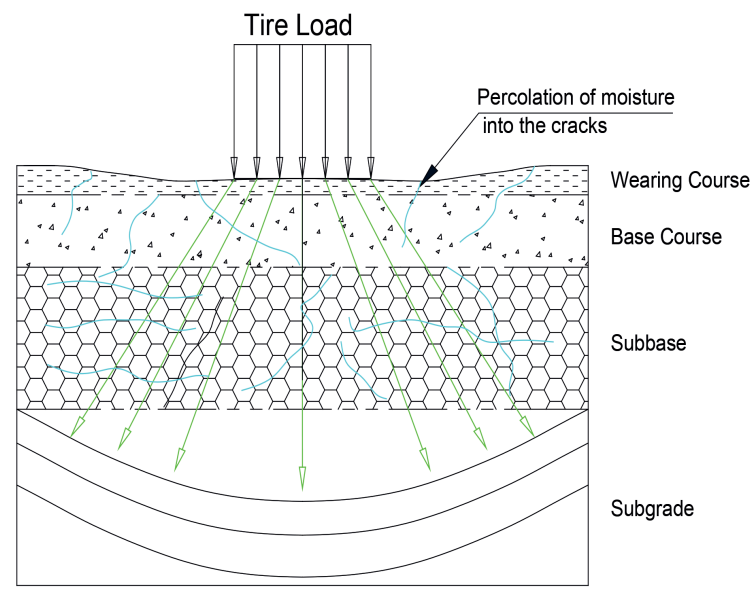

Fig. 1 Cross section of pavement with crack propagation at subgrade failure under traffic cyclic loading [2]

1. ábra Az útpálya keresztmetszete valamint a repedés terjedése az aljzat meghibásodásakor ciklikus forgalmi terhelés esetén

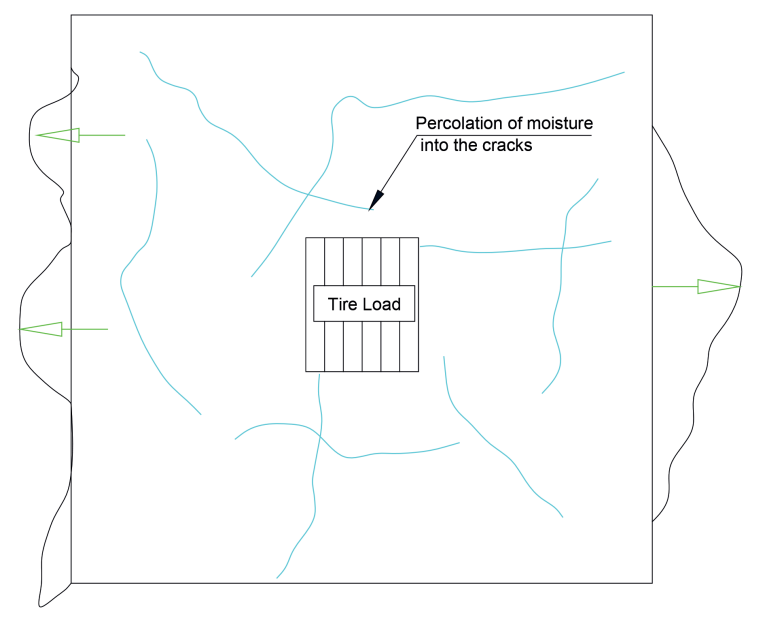

Fig. 2 Plan of pavement with crack propagation at subgrade failure under traffic cyclic loading [2]

2. ábra Az útpálya felülnézete valamint a repedés terjedése az aljzat meghibásodásakor ciklikus forgalmi terhelés esetén

\section{Materials and methods}

\subsection{Materials preparation}

$400 \mathrm{~g}$ of test lateritic soil was collected from distributed in hilly areas such as Soc Son District, Hanoi City and Hoa Binh Province of Vietnam. The disturbed sample was taped to remove lumps, sundried for 4 days and stored for the stabilization experimentation. The quarry dust material is in several Crush Rock Industries Areas in Ninh Binh Province such as Gia Vien District, Hoa Lu District, Hanoi, Vietnam, which satisfies design conditions in accordance with TCVN 
8857 [39]. It was also sundried to remove moisture and stored in silo bags for use. The waste glasses were collected from the dump sites across Hanoi. They were crushed with the $50 \mathrm{kN}$ crusher and also stored for use. The OPC used satisfied the requirement of cements used as binders in Vietnam construction industry [40-41]. The geopolymer cement (GPC) was synthesized with quarry dust (QD) and activator materials (Sodium Hydroxide $(\mathrm{NaOH})$ and Sodium Silicate $\left(\mathrm{Na}_{2} \mathrm{SiO}_{3}\right)$ ). Based on previous findings on the synthesis of GPCs [28, 29, $31,42-47]$, the quarry dust based Geopolymer was synthesized.

\subsection{Experimental methods}

The conventional tests that were conducted on the test soil for characterization and classification reasons are as follows;

i. Particle size distribution (PSD): this was conducted with vertically arranged sieve sizes mounted on an automatic shaker in accordance with BS 1377-2 and Nigerian General Specification [7, 48],

ii. Standard Proctor Compaction: this was conducted on the untreated soil with 2016 ELE Automatic Compactor Machine in accordance with BS 1377-2, and NGS [7, 48] and on the treated soil in accordance with BS 1924 [49],

iii. Consistency Limits: this was conducted using a 2013 cassagrande apparatus on the untreated soil in accordance with BS 1377-2, and NGS [7, 48] and on the treated soil specimens in accordance with BS 1924 [49],

iv. Specific Gravity test was conducted by Pycnometer method in accordance with BS 1377-2, and NGS $[7,48]$ and BS 1924 [49] for the untreated and the treated soils respectively,

v. Chemical Oxides Composition test on the test soils and the test materials with XRF method in accordance with BS 1377-2 and Nigerian GS [7, 48]

vi. And finally, California Bearing Ratio test (CBR): was conducted on the untreated and treated soils blended with 4, 8, 12, 16, and 20\% CWG and linearly inversely replaced cements of QDbGPC and DOPC in a ratio pattern of $0: 40,5: 35,10: 30,15: 25,20: 20,25: 15$, $30: 10,35: 5$, and $40: 0 \%$ by weight of solid. This was experimented with a 2015 S211 KIT CBR penetration machine, motorized 50kN ASTM used to load the penetration piston into the soil sample at a constant rate of $1.27 \mathrm{~mm} / \mathrm{min}(1 \mathrm{~mm} / \mathrm{min}$ to BS Spec.) and to measure the applied loads and piston's penetrations at determined intervals with which CBR values were computed using Eq. (1) and results were obtained. This was experimented in accordance with British standards, Vietnamese standards and AASHTO methods [48-54]

$$
C B R=\frac{P_{T}}{P_{S}} x 100
$$

Where;

$P_{T}=$ corrected unit test load corresponding to the chosen penetration from load penetration curve,

$P_{S}=$ the total standard load for the same depth of penetration which can be taken as $13.24 \mathrm{kN}$ for $2.5 \mathrm{~mm}$ penetration and $19.96 \mathrm{kN}$ for $5.0 \mathrm{~mm}$ penetration.

\section{Results and discussions}

\subsection{General behavior and classification of test materials}

The results of the experimental program have been presented in tables and graphs in the following pages. Test soil sample was investigated and characterized under the laboratory conditions with the preliminary test results presented in Tables 1 , and 2 and Fig. 3. The soil was classified as A-7-6 group according to the AASHTO classification method [51]. It was equally classified according to USCS as poorly graded (GP) soil. Additionally, the soil was observed as having high clay content and high free swell index (FSI). It was also classified as highly plastic with plasticity index above $17 \%$ and expansive. Table 3 presents that the test materials have high aluminosilicate content and possess pozzolanic properties [40]. Table 3 and Fig. 4 presents the oxide rates and bonding potentials of the test materials. This also satisfied that the material bonding is a very important factor in soil stabilization and strength development. This is because the soil and the admixture need to form a homogeneous and cohesive bond. Material requirement for cementitious materials states that the sum of the oxide rates of $\mathrm{SiO}_{2}, \mathrm{Al}_{2} \mathrm{O}_{3}$, and $\mathrm{Fe}_{2} \mathrm{O}_{3}$ should not be less than $70 \%$. The results of the analysed materials presented in Table 3 show that the percentage of $\mathrm{SiO}_{2}+\mathrm{Fe}_{2} \mathrm{O}_{3}+\mathrm{Al}_{2} \mathrm{O}_{3}$ for each of the materials is greater than $70 \%$. This behaviour makes the test material samples highly pozzolanic [40]. This property was of great advantage because it brought about a high degree of interaction, pozzolanic reaction, carbonation reaction and bonding between the studied soil and the synthesized GPC.

\begin{tabular}{cc}
$\begin{array}{c}\text { Property description of test } \\
\text { soils and units }\end{array}$ & Values \\
\% Passing Sieve No 200 & 38 \\
\hline NMC (\%) & 13.49 \\
\hline LL (\%) & 46 \\
\hline PL (\%) & 21 \\
\hline PI (\%) & 25 \\
\hline SL (\%) & 8 \\
\hline FSI (\%) & 234 \\
\hline$G$ s & 2.43 \\
\hline AASHTO Classification & $\mathrm{A}-7-6$ \\
\hline UCSC & GP \\
\hline MDD (g/cm $\left.{ }^{3}\right)$ & 1.85 \\
\hline OMC $(\%)$ & 16.2 \\
\hline CBR (\%) & 13 \\
\hline Colour & Reddish Grey
\end{tabular}

Table 1 Basic properties of test soils

1. táblázat A vizsgált talajok alapvető tulajdonságai

\begin{tabular}{lccccccccccc}
\multicolumn{1}{c}{\begin{tabular}{c} 
Mate- \\
\multicolumn{11}{c}{ rials }
\end{tabular}} & 19 & $\mathbf{6 . 3 5}$ & 4.75 & 2.36 & $\mathbf{1 . 1 8}$ & $\mathbf{0 . 6}$ & $\mathbf{0 . 4 2 5}$ & $\mathbf{0 . 3}$ & $\mathbf{0 . 1 5}$ & $\mathbf{0 . 0 7 5}$ & Pan \\
Test Soil & - & 100 & 91 & 82 & 63 & 50 & 39 & 28 & 21 & 10 & 0 \\
\hline $\begin{array}{l}\text { Quarry } \\
\text { Dust }\end{array}$ & 100 & 89 & 44 & 23 & 18 & 15 & 14 & 12 & 5 & 2 & 0 \\
\hline CWG & 100 & 96 & 82 & 76 & 63 & 54 & 47 & 39 & 24 & 19 & 0
\end{tabular}

Table 2 Particle size distribution (PSD) of test materials 2. táblázat A vizsgált anyagok szemmegoszlása 


\begin{tabular}{|c|c|c|c|c|c|c|c|c|c|c|c|c|c|}
\hline \multirow[b]{2}{*}{ Materials } & \multicolumn{13}{|c|}{ Oxides Composition (content wt \%) } \\
\hline & $\mathrm{SiO}_{2}$ & $\mathrm{Al}_{2} \mathrm{O}_{3}$ & $\mathrm{CaO}$ & $\mathrm{Fe}_{2} \mathrm{O}_{3}$ & MgO & $\mathrm{K}_{2} \mathrm{O}$ & $\mathrm{Na}_{2} \mathrm{O}$ & $\mathrm{TiO}_{2}$ & LOI & $\mathbf{P}_{2} \mathbf{O}_{5}$ & $\mathrm{SO}_{3}$ & IR & $\begin{array}{l}\text { Free } \\
\text { CaO }\end{array}$ \\
\hline Test soil & 76.56 & 15.09 & 2.30 & 2.66 & 0.89 & 2.10 & 0.33 & 0.07 & - & - & - & - & - \\
\hline Quarry Dust & 63.48 & 17.72 & 5.56 & 1.77 & 4.65 & 2.76 & 0.01 & 3.17 & 0.88 & - & - & - & - \\
\hline CWG & 73.5 & 0.78 & 8.11 & - & 1.79 & 2.09 & 11.0 & - & 1.89 & - & - & - & 0.8 \\
\hline DOPC & 21.45 & 4.45 & 63.81 & 3.07 & 2.42 & 0.83 & 0.20 & 0.22 & 0.81 & 0.11 & 2.46 & 0.16 & 0.64 \\
\hline
\end{tabular}

*IR is Insoluble Residue, LOI is Loss on Ignition, QD: Quarry Dust, DOPC: Dangote Ordinary Portland Cement, CWG: Crushed Waste Glasses

Table 3 Oxides composition of the materials used in this paper

3. táblázat A cikkben használt anyagok oxidos összetétele

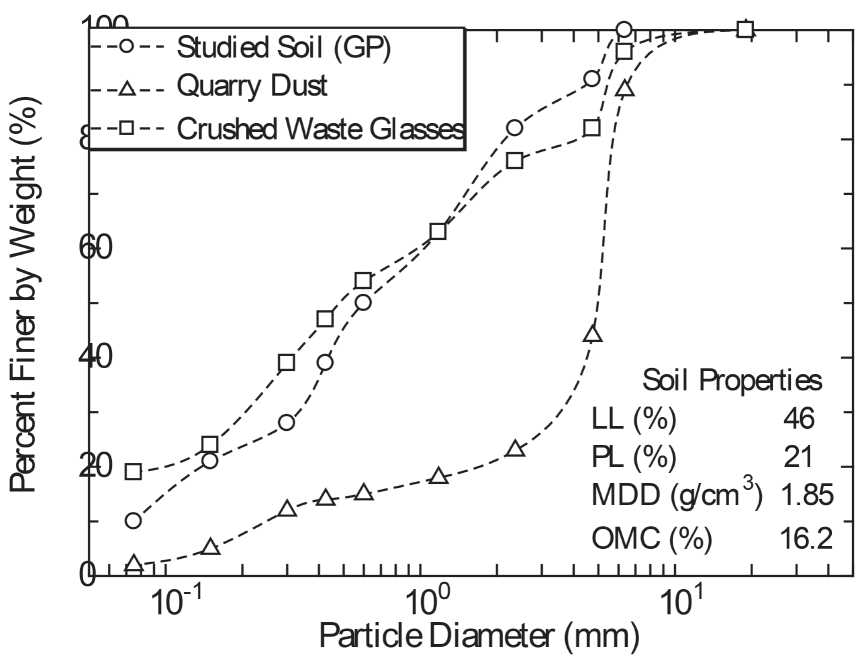

Fig. 3 Particle size distribution of studied materials

3. ábra A vizsgált anyagok szemmegoszlása

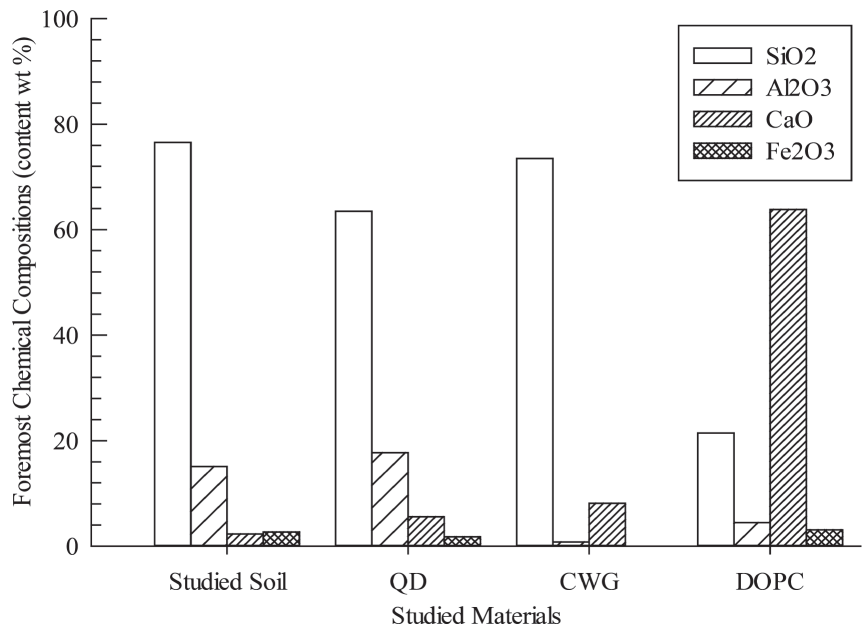

Fig. 4 Chemical oxides components in studied materials 4. ábra A vizsgált anyagok kémiai oxidos összetétele

\subsection{Compaction behaviour of QDbGPC: DOPC treated soil with crushed waste glasses (CWG)}

The compaction results are presented in Table 4 and Fig. 5. The compaction behaviour is the densification process observed on the QDbGPC/ DOPC treated soil under the influence of added proportions of crushed waste glasses. The test soil was observed to be an unstable soil and was treated alternately with QDbGPC and DOPC in the ratios of 0:0, 0:40, 5:35, 10:30, 15:25, 20:20, $25: 15,30: 10,35: 5$, and $40: 0 \%$ respectively. The effect of $4 \%, 8 \%$,
$12 \%, 16 \%$ and $20 \%$ by weight of crushed waste glasses over the cemented test soil was also observed. While 0:0\% of the cements proportion by weight of solid served as the control point, the proportions of GPC increased from 5\% in an increment of 5\% while DOPC decreased from $40 \%$ at the rate of $5 \%$ also. The maximum dry density of the test soil increased with increased proportion of GPC and decreased proportion of DOPC. This consistently continued until 40:0\% corresponding to GPC and DOPC respectively. The specific gravity also increased in that succession consistently. Alternatively, the optimum moisture content decreased with the same pattern. Notably, the introduction of the high content aluminosilicate crushed waste glasses improved the compaction characteristics of the test soil under the influence of the cements. This behaviour on the axes of the cements linear inverse replacement process was due to the introduction of a more bio-based cementing material, which is resistant to sulphate attacks, cracking and brittleness. Also, the bio-based cementing geomaterial i.e. the QDbGPC composite produced more silicate and aluminate to form $\mathrm{CSH}$ and $\mathrm{CAH}$ responsible for strength gain and densification $[2,56,57,58$, 59]. It forms more elastic agglomeration and sequestrum and flocs to produce a more densified treated soil. Cation exchange reactions between the dissociated ions from the bio-based cementing material caused the increased density and specific gravity with increased proportions of GPC. These increased MDD were obtained at optimum moisture content [60].

\subsection{Consistency behaviour of QDbGPC to DOPC treated soil with crushed waste glasses (CWG)}

Table 5 and Fig. 6 present the consistency behaviour of the quarry dust based geopolymer cement linearly and inversely replace ordinary Portland cement treated soil under laboratory conditions under crushed waste glasses added to the treatment procedure. The addition of CWG into the cemented soil reduced the liquid limits, plastic limits and the plasticity index consistently. This behaviour however shows that further addition of CWG beyond the maximum 40\% utilized in this exercise could have improved the consistency limits further. But very important to note was the improvements recorded with the linearly inversely introduction of the cements into the test soil. That is, while the bio-based geopolymer cement was increased in the treatment blend, the Portland cement was reduced and the effect of this treatment pattern was observed. Results have shown that increased quarry dust based geopolymer cement reduced the consistency limits from very high plastic condition to even very less plastic consistency. The 


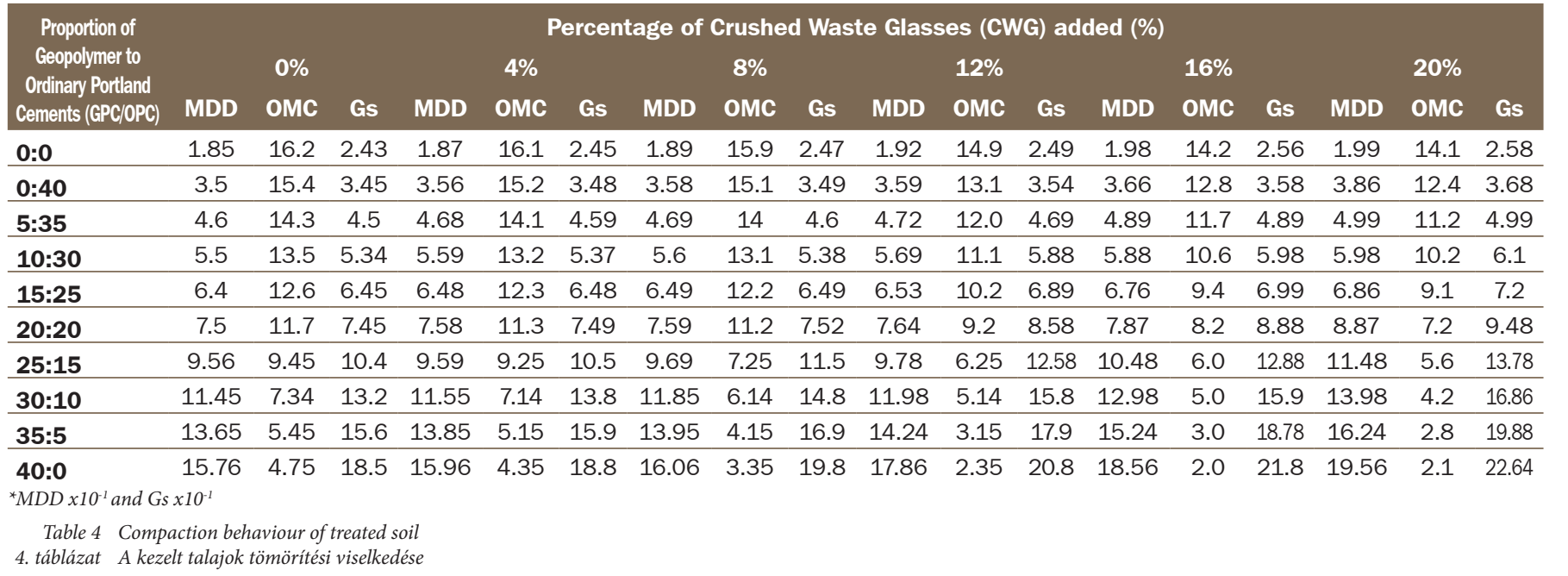

\begin{tabular}{|c|c|c|c|c|c|c|c|c|c|c|c|c|c|c|c|c|c|c|}
\hline \multirow{3}{*}{$\begin{array}{c}\text { Proportion of } \\
\text { Ceopolymer to } \\
\text { Ordinary Portland } \\
\text { Cements (GPC/OPC) }\end{array}$} & \multicolumn{18}{|c|}{ Percentage of Crushed Waste Glasses (CWG) added (\%) } \\
\hline & \multicolumn{3}{|c|}{$0 \%$} & \multicolumn{3}{|c|}{$4 \%$} & \multicolumn{3}{|c|}{$8 \%$} & \multicolumn{3}{|c|}{$12 \%$} & \multicolumn{3}{|c|}{$16 \%$} & \multicolumn{3}{|c|}{$20 \%$} \\
\hline & $\mathbf{L L}$ & PL & Ip & LL & PL & Ip & LL & $\mathbf{P L}$ & Ip & LL & PL & Ip & LL & PL & Ip & LL & PL & Ip \\
\hline $0: 0$ & 46 & 21 & 25 & 44 & 22 & 24 & 40 & 17 & 23 & 38 & 16 & 22 & 37 & 16 & 21 & 36 & 16 & 20 \\
\hline $0: 40$ & 43 & 21 & 22 & 42 & 21 & 21 & 38 & 18 & 20 & 37 & 17 & 20 & 35 & 16 & 19 & 34 & 15 & 19 \\
\hline 5:35 & 41 & 20 & 21 & 39 & 19 & 20 & 37 & 18 & 19 & 35 & 17 & 18 & 32 & 15 & 17 & 30 & 13 & 17 \\
\hline $10: 30$ & 38 & 18 & 20 & 36 & 17 & 19 & 34 & 16 & 18 & 32 & 15 & 17 & 30 & 14 & 16 & 28 & 13 & 15 \\
\hline $15: 25$ & 35 & 17 & 18 & 32 & 14 & 18 & 29 & 12 & 17 & 26 & 10 & 16 & 25 & 10 & 15 & 24 & 10 & 14 \\
\hline 20:20 & 31 & 15 & 16 & 30 & 15 & 15 & 27 & 13 & 14 & 24 & 11 & 13 & 23 & 11 & 12 & 21 & 10 & 11 \\
\hline 25:15 & 29 & 16 & 13 & 26 & 14 & 12 & 23 & 11 & 11 & 21 & 11 & 10 & 20 & 11 & 9 & 18 & 10 & 8 \\
\hline $30: 10$ & 25 & 15 & 10 & 22 & 13 & 9 & 19 & 11 & 8 & 17 & 10 & 7 & 15 & 9 & 6 & 14 & 9 & 5 \\
\hline $35: 5$ & 19 & 12 & 7 & 17 & 11 & 6 & 16 & 11 & 5 & 15 & 11 & 4 & 14 & 11 & 3 & 12 & 10 & 2 \\
\hline $40: 0$ & 16 & 12 & 4 & 14 & 11 & 3 & 12 & 9 & 3 & 10 & 8 & 2 & 10 & 9 & 1 & 9 & 8 & 1 \\
\hline
\end{tabular}

Table 5 Consistency behaviour of treated soil

5. táblázat A kezelés hatása a talajok konzisztenciájára

\begin{tabular}{|c|c|c|c|c|c|c|c|c|c|}
\hline \multirow[t]{3}{*}{ Plunger Penetration (mm) } & \multicolumn{9}{|c|}{ Plunger Load (kN) } \\
\hline & \multicolumn{9}{|c|}{ California bearing ratio behaviour of OPC $+Q D b G P C(\%)$ treated soil with $0 \%$ CWG } \\
\hline & 0 & $0+40$ & $5+35$ & $10+30$ & $20+20$ & $25+15$ & $30+10$ & $35+5$ & $40+0$ \\
\hline 0 & 0 & 0 & 0 & 0 & 0 & 0 & 0 & 0 & 0 \\
\hline 0.5 & 1.2 & 1.5 & 1.8 & 2.1 & 4.4 & 8.4 & 12.4 & 16.5 & 20.5 \\
\hline 1 & 1.3 & 1.6 & 1.9 & 2.2 & 4.5 & 8.5 & 12.5 & 16.6 & 20.6 \\
\hline 1.5 & 1.5 & 1.7 & 2.0 & 2.3 & 4.6 & 8.6 & 12.6 & 16.7 & 20.7 \\
\hline 2 & 1.7 & 1.8 & 2.1 & 2.4 & 4.7 & 8.7 & 12.7 & 16.8 & 20.8 \\
\hline 2.5 & 1.8 & 1.9 & 2.2 & 2.5 & 4.8 & 8.8 & 12.8 & 16.9 & 20.9 \\
\hline 3 & 2.0 & 2.1 & 2.3 & 2.6 & 4.9 & 8.9 & 12.9 & 17.0 & 21.0 \\
\hline 3.5 & 2.1 & 2.2 & 2.4 & 2.7 & 5.0 & 9.0 & 13.0 & 17.1 & 21.1 \\
\hline 4 & 2.2 & 2.3 & 2.5 & 2.8 & 5.1 & 9.1 & 13.1 & 17.2 & 21.2 \\
\hline 4.5 & 2.3 & 2.4 & 2.6 & 2.9 & 5.2 & 9.2 & 13.2 & 17.3 & 21.3 \\
\hline 5 & 2.4 & 2.5 & 2.7 & 3.0 & 5.3 & 9.3 & 13.3 & 17.4 & 21.4 \\
\hline 5.5 & 2.6 & 2.7 & 2.8 & 3.1 & 5.4 & 9.4 & 13.4 & 17.5 & 21.5 \\
\hline 6 & 2.7 & 2.8 & 2.9 & 3.2 & 5.5 & 9.5 & 13.5 & 17.6 & 21.6 \\
\hline 6.5 & 2.9 & 2.9 & 3.0 & 3.3 & 5.6 & 9.6 & 13.6 & 17.7 & 21.7 \\
\hline 7 & 3.2 & 3.3 & 3.4 & 3.5 & 5.7 & 9.7 & 13.7 & 17.8 & 21.8 \\
\hline 7.5 & 3.6 & 3.7 & 3.8 & 3.7 & 5.8 & 9.8 & 13.8 & 17.9 & 21.9 \\
\hline 8 & 3.8 & 3.9 & 4.0 & 4.1 & 6.2 & 9.9 & 13.9 & 18.0 & 22.0 \\
\hline 8.5 & 4.1 & 4.2 & 4.3 & 4.4 & 6.5 & 10.0 & 14.0 & 18.1 & 22.1 \\
\hline 9 & 4.3 & 4.4 & 4.5 & 4.6 & 6.7 & 10.1 & 14.1 & 18.2 & 22.2 \\
\hline 9.5 & 4.4 & 4.5 & 4.6 & 4.7 & 6.8 & 10.2 & 14.2 & 18.3 & 22.3 \\
\hline 10 & 4.5 & 4.6 & 4.7 & 4.8 & 6.9 & 10.3 & 14.3 & 18.4 & 22.4 \\
\hline
\end{tabular}

Table 6 California bearing ratio behaviour of OPC+QDbGPC (\%) treated soil with $0 \% C W G$

6. táblázat OPC+QDbGPC-vel kezelt talaj kaliforniai teherbírási értéke (0\% CWG esetén) 


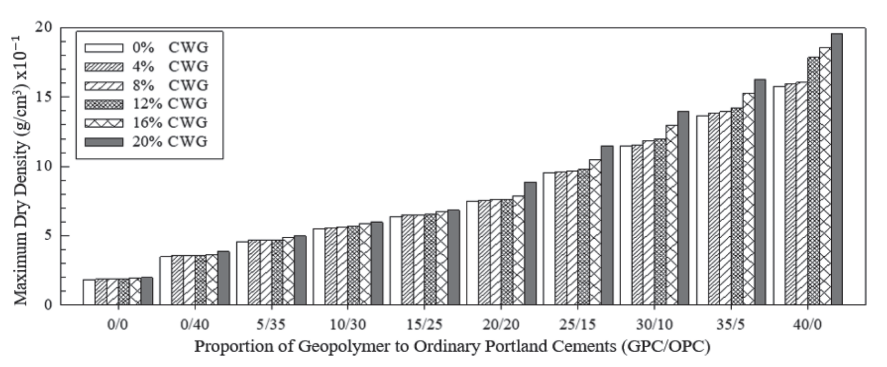

(a)

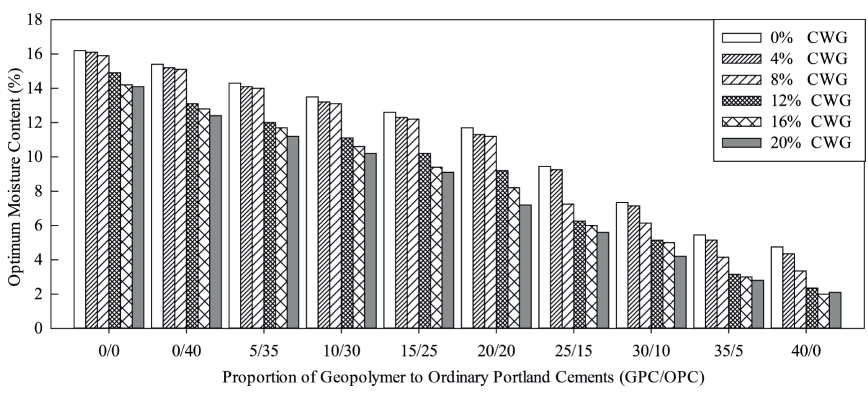

(b)

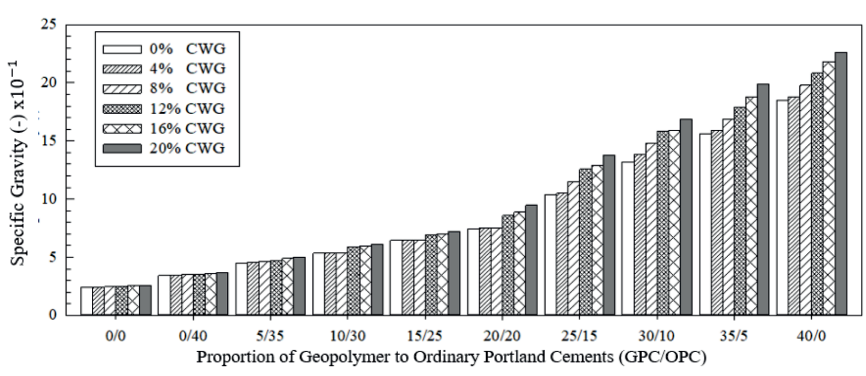

(c)

Fig. 5 Influences of crushed waste glasses on compaction behaviour of treated soil: (a) maximum dry density $\left(x 10^{-1}\right)$, (b) optimum moisture content, (c) specific gravity $\left(x 10^{-1}\right)$

5. ábra Zúzott üveghulladék hatása a kezelt talajok tömörödési viselkedésén: (a) maximális száraz testsürüség $\left(x 10^{-1}\right)$, (b) optimális nedvesség tartalom, $(c)$ fajsúly $\left(x 10^{-1}\right)$

hydration of the stabilized mixture and its increased calcination and pozzolanic activity have contributed to the behaviour of the soil. And also due to molecular rearrangement in the formation of transitional compounds [2]. This improvement is due to the hydration of the highly silicate-based pozzolanic additives from the quarry dust based geopolymer cement (QDbGPC) with the treated soil matrix, which reduced the PI consistently thereby producing a stiff mixture of stabilized soil. Also, the release of more cations from the biomass based geomaterials and quarry dust during the cation exchange reaction has contributed to the behaviour of the stabilized mixture. This behaviour agrees with Little et al. [61], which showed that if water is used as pore fluid, the influence of the mechanical factors would remain same with a general decrease in LL and PI on addition of an admixture and binder. The prone to cracks and brittle behaviour of Portland treated soils has contributed to the improved consistency limits at reduced rates of the DOPC [2].

\subsection{California bearing ratio behaviour of OPC plus} QDbGPC treated soil with crushed waste glasses (CWG)

CBR test was conducted to determine the untreated and treated soils resistance to shear failure when subjected to axial loads. Traffic loads are axial dynamic loads pavement facilities

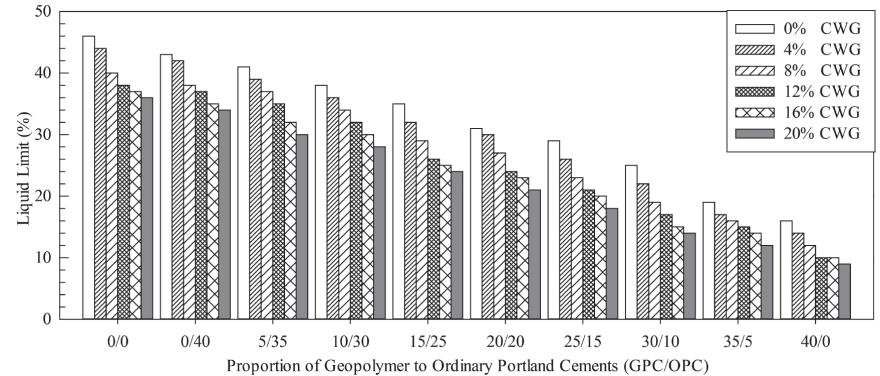

(a)

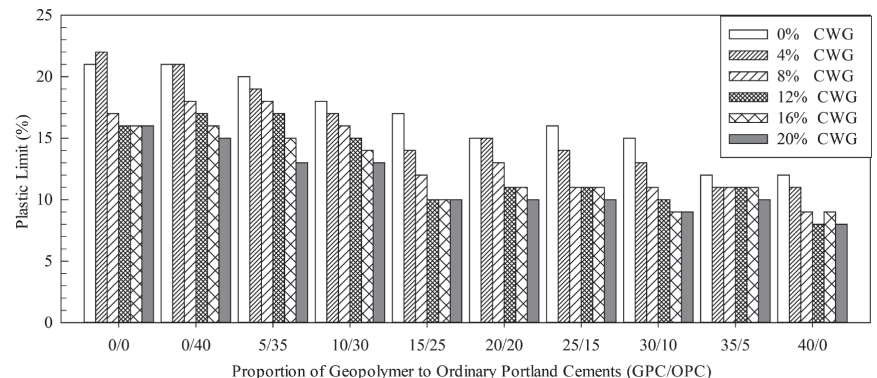

(b)

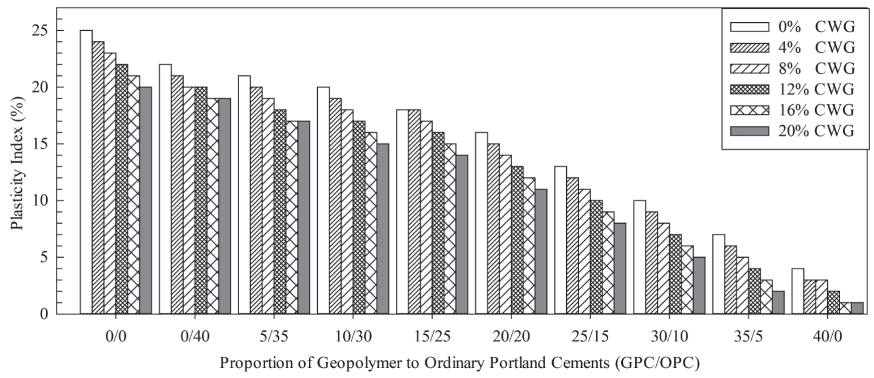

(c)

Fig. 6 Influences of crushed waste glasses on consistency behaviour of treated soil (a) Liquid limits, (b) Plastic limit, and (c) Plasticity index

6. ábra Zúzott üveghulladék hatása a kezelt talajok konzisztenciájára: (a) Sodrási határ, (b) Folyási határ, (c) Plasztikus index

are exposed to from vehicles of various sizes and penetration pressures. Pavements and pavement foundation fail by shear or lateral displacement (deformation). Hence it is important to observe the rigidity or stiffness of subgrade materials used as underlain structures. The CBR behaviour results of the underlain subgrade soil were presented in Tables 6-12 and Figs. $7 \& 8$. The studied soil was observed to be an expansive soil and was treated alternately with QDbGPC and OPC in the ratios of 0:0, 0:40, 5:35, 10:30, 15:25, 20:20, 25:15, 30:10, $35: 5$, and $40: 0 \%$ by weight respectively. The effect of $4 \%, 8 \%$, $12 \%, 16 \%$ and $20 \%$ by weight of crushed waste glasses over the cemented test soil was also observed. While $0: 0 \%$ of the cements proportion by weight of solid served as the control point, the proportions of GPC increased from 5\% in an increment of 5\% while OPC decreased from $40 \%$ at the rate of $5 \%$ also. There was a consistent improvement on the CBR value of the treated soil with increased QDGbGPC and reduced DOPC proportions. These improved CBR values were greater than $20 \%$, and satisfy the material condition for use as improved subgrade material on Nigeria's dilapidated roads [7]. The consistently increased CBR values with the addition of QDGbGPC was due to the presence of adequate amount of calcium required for the formation of Calcium Silicate Hydrate (CSH) and Calcium Aluminate Hydrate 


\begin{tabular}{|c|c|c|c|c|c|c|c|c|c|}
\hline \multirow{3}{*}{$\begin{array}{c}\text { Plunger } \\
\text { Penetration } \\
(\mathbf{m m})\end{array}$} & \multicolumn{9}{|c|}{ Plunger Load (kN) } \\
\hline & \multicolumn{9}{|c|}{ California bearing ratio behaviour of OPC+QDbGPC (\%) treated soil with $4 \%$ CWG } \\
\hline & $\mathbf{0}$ & $0+40$ & $5+35$ & $10+30$ & $20+20$ & $25+15$ & $30+10$ & $35+5$ & $40+0$ \\
\hline 0 & 0 & 0 & 0 & 0 & 0 & 0 & 0 & 0 & 0 \\
\hline 0.5 & 1.3 & 1.6 & 1.9 & 2.2 & 4.5 & 8.5 & 12.5 & 16.6 & 20.6 \\
\hline 1 & 1.4 & 1.7 & 2.0 & 2.3 & 4.6 & 8.6 & 12.6 & 16.7 & 20.7 \\
\hline 1.5 & 1.6 & 1.8 & 2.1 & 2.4 & 4.7 & 8.7 & 12.7 & 16.8 & 20.8 \\
\hline 2 & 1.8 & 1.9 & 2.2 & 2.5 & 4.8 & 8.8 & 12.8 & 16.9 & 20.9 \\
\hline 2.5 & 1.9 & 2.0 & 2.3 & 2.6 & 4.9 & 8.9 & 12.9 & 17.0 & 21.0 \\
\hline 3 & 2.1 & 2.2 & 2.4 & 2.7 & 5.0 & 9.0 & 13.0 & 17.1 & 21.1 \\
\hline 3.5 & 2.2 & 2.3 & 2.5 & 2.8 & 5.1 & 9.1 & 13.1 & 17.2 & 21.2 \\
\hline 4 & 2.3 & 2.4 & 2.6 & 2.9 & 5.2 & 9.2 & 13.3 & 17.3 & 21.3 \\
\hline 4.5 & 2.4 & 2.5 & 2.7 & 3.0 & 5.3 & 9.3 & 13.4 & 17.4 & 21.4 \\
\hline 5 & 2.5 & 2.6 & 2.8 & 3.1 & 5.4 & 9.4 & 13.5 & 17.5 & 21.5 \\
\hline 5.5 & 2.7 & 2.7 & 2.9 & 3.2 & 5.5 & 9.5 & 13.6 & 17.6 & 21.6 \\
\hline 6 & 2.8 & 2.9 & 3.0 & 3.3 & 5.6 & 9.6 & 13.7 & 17.7 & 21.7 \\
\hline 6.5 & 3.0 & 3.1 & 3.1 & 3.4 & 5.7 & 9.6 & 13.8 & 17.8 & 21.8 \\
\hline 7 & 3.3 & 3.4 & 3.5 & 3.6 & 5.8 & 9.8 & 13.9 & 17.9 & 21.9 \\
\hline 7.5 & 3.7 & 3.8 & 3.9 & 3.8 & 5.9 & 9.9 & 14.0 & 18.0 & 22.0 \\
\hline 8 & 3.9 & 4.0 & 4.1 & 4.2 & 6.3 & 10.0 & 14.1 & 18.1 & 22.1 \\
\hline 8.5 & 4.2 & 4.3 & 4.4 & 4.5 & 6.6 & 10.1 & 14.2 & 18.2 & 22.2 \\
\hline 9 & 4.3 & 4.5 & 4.6 & 4.7 & 6.8 & 10.2 & 14.3 & 18.3 & 22.3 \\
\hline 9.5 & 4.5 & 4.6 & 4.7 & 4.8 & 6.9 & 10.3 & 14.3 & 18.4 & 22.4 \\
\hline 10 & 4.6 & 4.7 & 4.8 & 4.9 & 7.0 & 10.4 & 14.4 & 18.5 & 22.5 \\
\hline
\end{tabular}

Table 7 California bearing ratio behaviour of OPC+QDbGPC (\%) treated soil with $4 \%$ CWG

7. táblázat OPC+QDbGPC-vel kezelt talaj kaliforniai teherbírási értéke (4\% CWG esetén)

\begin{tabular}{|c|c|c|c|c|c|c|c|c|c|}
\hline \multirow[t]{2}{*}{$\begin{array}{l}\text { Plunger } \\
\text { Penetration } \\
\text { (mm) }\end{array}$} & \multicolumn{9}{|c|}{ Plunger Load (kN) } \\
\hline & 0 & $0+40$ & $5+35$ & $10+30$ & $20+20$ & $25+15$ & $30+10$ & $35+5$ & $40+0$ \\
\hline 0 & 0 & 0 & 0 & 0 & 0 & 0 & 0 & 0 & 0 \\
\hline 0.5 & 1.4 & 1.7 & 2.1 & 2.3 & 4.6 & 8.6 & 12.6 & 16.7 & 20.7 \\
\hline 1 & 1.5 & 1.8 & 2.2 & 2.4 & 4.7 & 8.7 & 12.7 & 16.8 & 20.8 \\
\hline 1.5 & 1.7 & 1.9 & 2.3 & 2.5 & 4.8 & 8.8 & 12.8 & 16.9 & 20.9 \\
\hline 2 & 1.9 & 2.1 & 2.3 & 2.6 & 4.9 & 8.9 & 12.9 & 17.0 & 21.0 \\
\hline 2.5 & 2.1 & 2.1 & 2.4 & 2.7 & 5.0 & 9.0 & 13.0 & 17.1 & 21.1 \\
\hline 3 & 2.2 & 2.3 & 2.5 & 2.8 & 5.1 & 9.1 & 13.1 & 17.2 & 21.2 \\
\hline 3.5 & 2.3 & 2.4 & 2.6 & 2.9 & 5.2 & 9.2 & 13.2 & 17.3 & 21.3 \\
\hline 4 & 2.4 & 2.5 & 2.7 & 3.0 & 5.3 & 9.3 & 13.3 & 17.4 & 21.4 \\
\hline 4.5 & 2.5 & 2.6 & 2.8 & 3.1 & 5.4 & 9.4 & 13.5 & 17.5 & 21.5 \\
\hline 5 & 2.6 & 2.7 & 2.9 & 3.2 & 5.5 & 9.5 & 13.6 & 17.6 & 21.6 \\
\hline 5.5 & 2.8 & 2.9 & 3.0 & 3.3 & 5.6 & 9.6 & 13.7 & 17.7 & 21.7 \\
\hline 6 & 2.9 & 3.0 & 3.0 & 3.4 & 5.7 & 9.7 & 13.8 & 17.8 & 21.8 \\
\hline 6.5 & 3.1 & 3.2 & 3.2 & 3.5 & 5.8 & 9.8 & 13.9 & 17.9 & 21.9 \\
\hline 7 & 3.4 & 3.5 & 3.6 & 3.7 & 5.9 & 9.9 & 14.0 & 18.0 & 22.0 \\
\hline 7.5 & 3.8 & 3.9 & 4.0 & 4.1 & 6.0 & 10.0 & 14.1 & 18.1 & 22.1 \\
\hline 8 & 4.0 & 4.1 & 4.2 & 4.3 & 6.4 & 10.1 & 14.2 & 18.2 & 22.2 \\
\hline 8.5 & 4.3 & 4.4 & 4.5 & 4.6 & 6.7 & 10.2 & 14.3 & 18.3 & 22.3 \\
\hline 9 & 4.4 & 4.6 & 4.7 & 4.8 & 6.9 & 10.3 & 14.4 & 18.4 & 22.4 \\
\hline 9.5 & 4.6 & 4.7 & 4.8 & 4.9 & 7.0 & 10.4 & 14.5 & 18.5 & 22.5 \\
\hline 10 & 4.7 & 4.8 & 4.9 & 5.0 & 7.1 & 10.5 & 14.6 & 18.6 & 22.6 \\
\hline
\end{tabular}

Table 8 California bearing ratio behaviour of OPC+QDbGPC (\%) treated soil with $8 \%$ CWG

8. táblázat $\mathrm{OPC}+\mathrm{QDbGPC}$-vel kezelt talaj kaliforniai teherbirási értéke (8\% CWG esetén) 


\begin{tabular}{|c|c|c|c|c|c|c|c|c|c|}
\hline \multirow{3}{*}{$\begin{array}{l}\text { Plunger } \\
\text { Penetration } \\
\text { (mm) }\end{array}$} & \multicolumn{9}{|c|}{ Plunger Load (kN) } \\
\hline & \multicolumn{9}{|c|}{ California bearing ratio behaviour of OPC + QDbGPC (\%) treated soil with $12 \%$ CWG } \\
\hline & 0 & $0+40$ & $5+35$ & $10+30$ & $20+20$ & $25+15$ & $30+10$ & $35+5$ & $40+0$ \\
\hline 0 & 0 & 0 & 0 & 0 & 0 & 0 & 0 & 0 & 0 \\
\hline 0.5 & 1.5 & 1.8 & 2.2 & 2.4 & 4.7 & 8.7 & 12.7 & 16.8 & 20.8 \\
\hline 1 & 1.6 & 1.9 & 2.3 & 2.5 & 4.8 & 8.8 & 12.8 & 16.9 & 20.9 \\
\hline 1.5 & 1.8 & 2.0 & 2.4 & 2.6 & 4.9 & 8.9 & 12.9 & 17.0 & 21.0 \\
\hline 2 & 2.0 & 2.2 & 2.5 & 2.7 & 5.0 & 9.0 & 13.0 & 17.1 & 21.1 \\
\hline 2.5 & 2.2 & 2.3 & 2.6 & 2.8 & 5.1 & 9.1 & 13.1 & 17.2 & 21.2 \\
\hline 3 & 2.3 & 2.4 & 2.7 & 2.9 & 5.2 & 9.2 & 13.2 & 17.3 & 21.3 \\
\hline 3.5 & 2.4 & 2.5 & 2.8 & 3.0 & 5.3 & 9.3 & 13.3 & 17.4 & 21.4 \\
\hline 4 & 2.5 & 2.6 & 2.9 & 3.1 & 5.4 & 9.4 & 13.4 & 17.5 & 21.5 \\
\hline 4.5 & 2.6 & 2.7 & 3.0 & 3.2 & 5.5 & 9.5 & 13.6 & 17.6 & 21.6 \\
\hline 5 & 2.7 & 2.8 & 3.1 & 3.3 & 5.6 & 9.6 & 13.7 & 17.7 & 21.7 \\
\hline 5.5 & 2.9 & 3.0 & 3.2 & 3.4 & 5.7 & 9.7 & 13.8 & 17.8 & 21.8 \\
\hline 6 & 3.0 & 3.1 & 3.3 & 3.5 & 5.8 & 9.8 & 13.9 & 17.9 & 21.9 \\
\hline 6.5 & 3.2 & 3.3 & 3.4 & 3.6 & 5.9 & 9.9 & 14.0 & 18.0 & 22.0 \\
\hline 7 & 3.5 & 3.6 & 3.7 & 3.8 & 6.0 & 10.0 & 14.1 & 18.1 & 22.1 \\
\hline 7.5 & 3.9 & 4.0 & 4.1 & 4.2 & 6.1 & 10.1 & 14.2 & 18.2 & 22.2 \\
\hline 8 & 4.1 & 4.2 & 4.3 & 4.4 & 6.5 & 10.2 & 14.3 & 18.3 & 22.3 \\
\hline 8.5 & 4.4 & 4.5 & 4.6 & 4.7 & 6.8 & 10.3 & 14.4 & 18.4 & 22.4 \\
\hline 9 & 4.5 & 4.7 & 4.8 & 4.9 & 7.0 & 10.4 & 14.5 & 18.5 & 22.5 \\
\hline 9.5 & 4.7 & 4.8 & 4.9 & 5.0 & 7.1 & 10.5 & 14.6 & 18.6 & 22.6 \\
\hline 10 & 4.8 & 4.9 & 5.0 & 5.1 & 7.2 & 10.6 & 14.7 & 18.7 & 22.7 \\
\hline
\end{tabular}

Table 9 California bearing ratio behaviour of OPC+QDbGPC (\%) treated soil with $12 \%$ CWG 9. táblázat OPC+QDbGPC-vel kezelt talaj kaliforniai teherbírási értéke (12\% CWG esetén)

\begin{tabular}{|c|c|c|c|c|c|c|c|c|c|}
\hline \multirow{2}{*}{$\begin{array}{l}\text { Plunger } \\
\text { Penetration } \\
(\mathrm{mm})\end{array}$} & \multicolumn{9}{|c|}{ California bearing ratio behaviour of DOPC+QDbGPC (\%) treated soil with $16 \%$ CWG } \\
\hline & $\mathbf{0}$ & $0+40$ & $5+35$ & $10+30$ & $20+20$ & $25+15$ & $30+10$ & $35+5$ & $40+0$ \\
\hline 0 & 0 & 0 & 0 & 0 & 0 & 0 & 0 & 0 & 0 \\
\hline 0.5 & 1.6 & 1.9 & 2.3 & 2.5 & 4.8 & 8.8 & 12.8 & 16.9 & 20.9 \\
\hline 1 & 1.7 & 2.1 & 2.4 & 2.6 & 4.9 & 8.9 & 12.9 & 17.0 & 21.0 \\
\hline 1.5 & 1.9 & 2.2 & 2.5 & 2.7 & 5.0 & 9.0 & 13.0 & 17.1 & 21.1 \\
\hline 2 & 2.1 & 2.3 & 2.6 & 2.8 & 5.1 & 9.1 & 13.1 & 17.2 & 21.2 \\
\hline 2.5 & 2.3 & 2.4 & 2.6 & 2.9 & 5.2 & 9.2 & 13.2 & 17.3 & 21.3 \\
\hline 3 & 2.4 & 2.5 & 2.8 & 3.0 & 5.3 & 9.3 & 13.3 & 17.4 & 21.4 \\
\hline 3.5 & 2.5 & 2.6 & 2.9 & 3.1 & 5.4 & 9.4 & 13.4 & 17.5 & 21.5 \\
\hline 4 & 2.6 & 2.7 & 3.0 & 3.2 & 5.5 & 9.5 & 13.5 & 17.6 & 21.6 \\
\hline 4.5 & 2.7 & 2.8 & 3.1 & 3.3 & 5.6 & 9.6 & 13.7 & 17.7 & 21.7 \\
\hline 5 & 2.8 & 2.9 & 3.2 & 3.4 & 5.7 & 9.7 & 13.8 & 17.8 & 21.8 \\
\hline 5.5 & 3.0 & 3.1 & 3.3 & 3.5 & 5.8 & 9.8 & 13.9 & 17.9 & 21.9 \\
\hline 6 & 3.1 & 3.2 & 3.4 & 3.6 & 5.9 & 9.9 & 14.0 & 18.0 & 22.0 \\
\hline 6.5 & 3.3 & 3.4 & 3.5 & 3.7 & 6.0 & 10.0 & 14.1 & 18.1 & 22.1 \\
\hline 7 & 3.6 & 3.7 & 3.8 & 3.9 & 6.1 & 10.1 & 14.2 & 18.2 & 22.2 \\
\hline 7.5 & 4.0 & 4.1 & 4.2 & 4.3 & 6.2 & 10.2 & 14.3 & 18.3 & 22.3 \\
\hline 8 & 4.2 & 4.3 & 4.4 & 4.5 & 6.6 & 10.3 & 14.4 & 18.4 & 22.4 \\
\hline 8.5 & 4.5 & 4.6 & 4.7 & 4.8 & 6.9 & 10.4 & 14.5 & 18.5 & 22.5 \\
\hline 9 & 4.6 & 4.7 & 4.9 & 5.0 & 7.0 & 10.5 & 14.6 & 18.6 & 22.6 \\
\hline 9.5 & 4.8 & 4.9 & 5.0 & 5.1 & 7.2 & 10.6 & 14.7 & 18.7 & 22.7 \\
\hline 10 & 4.9 & 5.0 & 5.1 & 5.2 & 7.3 & 10.7 & 14.8 & 18.8 & 22.8 \\
\hline
\end{tabular}

Table 10 California bearing ratio behaviour of DOPC+QDbGPC (\%) treated soil with $16 \%$ CWG

10. táblázat OPC+QDbGPC-vel kezelt talaj kaliforniai teherbírási értéke (16\% CWG esetén) 


\begin{tabular}{|c|c|c|c|c|c|c|c|c|c|}
\hline \multirow{3}{*}{$\begin{array}{c}\text { Plunger } \\
\text { Penetration } \\
(\mathrm{mm})\end{array}$} & \multicolumn{9}{|c|}{ Plunger Load (kN) } \\
\hline & \multicolumn{9}{|c|}{ California bearing ratio behaviour of OPC+QDbGPC (\%) treated soil with $20 \%$ CWG } \\
\hline & 0 & $0+40$ & $5+35$ & $10+30$ & $20+20$ & $25+15$ & $30+10$ & $35+5$ & $40+0$ \\
\hline 0 & 0 & 0 & 0 & 0 & 0 & 0 & 0 & 0 & 0 \\
\hline 0.5 & 1.7 & 2.0 & 2.3 & 2.6 & 4.9 & 8.9 & 12.9 & 17.0 & 21.0 \\
\hline 1 & 1.8 & 2.2 & 2.5 & 2.7 & 5.0 & 9.0 & 13.0 & 17.1 & 21.1 \\
\hline 1.5 & 2.0 & 2.3 & 2.6 & 2.8 & 5.1 & 9.1 & 13.1 & 17.2 & 21.2 \\
\hline 2 & 2.2 & 2.4 & 2.7 & 2.9 & 5.2 & 9.2 & 13.2 & 17.3 & 21.3 \\
\hline 2.5 & 2.4 & 2.5 & 2.8 & 3.0 & 5.3 & 9.3 & 13.3 & 17.4 & 21.4 \\
\hline 3 & 2.5 & 2.6 & 2.9 & 3.1 & 5.4 & 9.4 & 13.4 & 17.5 & 21.5 \\
\hline 3.5 & 2.6 & 2.7 & 3.0 & 3.2 & 5.5 & 9.5 & 13.5 & 17.6 & 21.6 \\
\hline 4 & 2.7 & 2.8 & 3.1 & 3.3 & 5.6 & 9.6 & 13.6 & 17.7 & 21.7 \\
\hline 4.5 & 2.8 & 2.9 & 3.2 & 3.4 & 5.7 & 9.7 & 13.8 & 17.8 & 21.8 \\
\hline 5 & 2.9 & 3.0 & 3.3 & 3.5 & 5.8 & 9.8 & 13.9 & 17.9 & 21.9 \\
\hline 5.5 & 3.1 & 3.2 & 3.4 & 3.6 & 5.9 & 9.9 & 14.0 & 18.0 & 22.0 \\
\hline 6 & 3.2 & 3.3 & 3.5 & 3.7 & 6.0 & 10.0 & 14.1 & 18.1 & 22.1 \\
\hline 6.5 & 3.4 & 3.5 & 3.6 & 3.8 & 6.1 & 10.1 & 14.2 & 18.2 & 22.2 \\
\hline 7 & 3.7 & 3.8 & 3.9 & 4.0 & 6.2 & 10.2 & 14.3 & 18.3 & 22.3 \\
\hline 7.5 & 4.1 & 4.2 & 4.3 & 4.4 & 6.3 & 10.3 & 14.4 & 18.4 & 22.4 \\
\hline 8 & 4.3 & 4.4 & 4.5 & 4.6 & 6.7 & 10.4 & 14.5 & 18.5 & 22.5 \\
\hline 8.5 & 4.6 & 4.7 & 4.8 & 4.9 & 7.0 & 10.5 & 14.6 & 18.6 & 22.6 \\
\hline 9 & 4.7 & 4.8 & 4.9 & 5.1 & 7.1 & 10.6 & 14.7 & 18.7 & 22.7 \\
\hline 9.5 & 4.9 & 5.0 & 5.1 & 5.2 & 7.3 & 10.7 & 14.8 & 18.8 & 22.8 \\
\hline 10 & 5.0 & 5.1 & 5.2 & 5.3 & 7.4 & 10.8 & 14.9 & 18.9 & 22.9 \\
\hline
\end{tabular}

Table 11 California bearing ratio behaviour of OPC+QDbGPC (\%) treated soil with $20 \%$ CWG 11. táblázat OPC+QDbGPC-vel kezelt talaj kaliforniai teherbirási értéke (20\% CWG esetén)
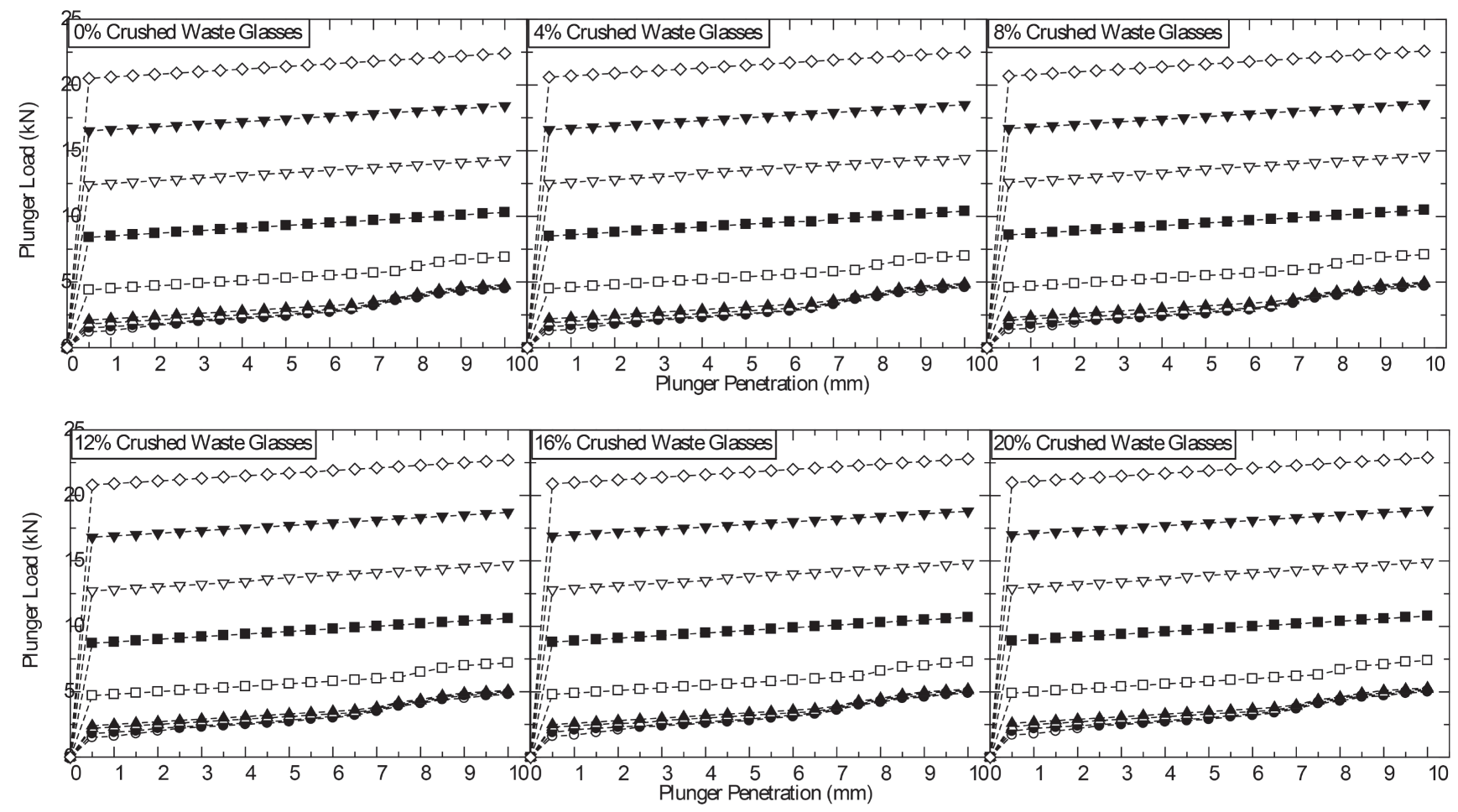

\begin{tabular}{|c|c|c|}
\hline $\begin{array}{l}--\circ-\text { GPC }: \text { OPC }=0: 0 \\
--- \text { GPC }: \text { OPC }=0: 40 \\
--- \text { GPC }: \text { OPC }=5: 35\end{array}$ & $\begin{array}{l} \\
--\end{array}$ & $\begin{array}{l}--\nabla-- \text { GPC }: \text { OPC }=30: 10 \\
---- \text { GPC }: \text { OPC }=35: 5 \\
--\diamond-- \text { GPC }: \text { OPC }=40: 0\end{array}$ \\
\hline
\end{tabular}

Fig. 7 Effect of crushed waste glasses proportion on the CBR behaviour of DOPC+QDbGPC (\%) treated soil

7. ábra Zúzott üveghulladék arányának hatása a $D O P C+Q D b G P C$-vel kezelt talaj kaliforniai teherbirási értékére 


\begin{tabular}{|c|c|c|c|c|c|c|c|c|c|}
\hline \multirow{2}{*}{$\begin{array}{l}\text { CWG Propor- } \\
\text { tion by wt (\%) }\end{array}$} & \multicolumn{9}{|c|}{ CBR of DOPC+QDbGPC (\%) treated soil with CWG } \\
\hline & 0 & $0+40$ & $5+35$ & $10+30$ & $20+20$ & $25+15$ & $30+10$ & $35+5$ & $40+0$ \\
\hline 0 & 13 & 14 & 17 & 19 & 36 & 66 & 97 & 128 & 158 \\
\hline 4 & 14 & 15 & 17 & 20 & 37 & 67 & 97 & 128 & 159 \\
\hline 8 & 16 & 16 & 18 & 20 & 38 & 68 & 98 & 129 & 159 \\
\hline 12 & 17 & 17 & 20 & 21 & 39 & 69 & 99 & 130 & 160 \\
\hline 16 & 17 & 18 & 20 & 22 & 39 & 69 & 100 & 131 & 161 \\
\hline 20 & 18 & 19 & 21 & 23 & 40 & 70 & 100 & 131 & 162 \\
\hline
\end{tabular}

Table 12 California bearing ratio of DOPC+QDbGPC (\%) treated soil with CWG 12. táblázat $C W G$ tartalmú DOPC+QDbGPC-vel kezelt talaj kaliforniai teherbírási értéke

(CAH), which are the major compounds responsible for the formation of sequestrum, flocs and strength development $[1,2]$. The soil + QDbGPC blends at 40:0\% by weight cementation met the minimum requirement for $\mathrm{CBR}$ value of $20-30 \%$ specified by Dogbey and Gidigasu [60] for materials suitability for use as base course materials when determined at MDD and OMC. Increase in $\mathrm{CBR}$ value, was an indication of the improvement observed in MDD, which is attributed to the compatibility of the grains of soil due to the increased cations released and the high pozzolanic and silicate properties of the QDbGPC such that greater polycondensation and densification were achieved.

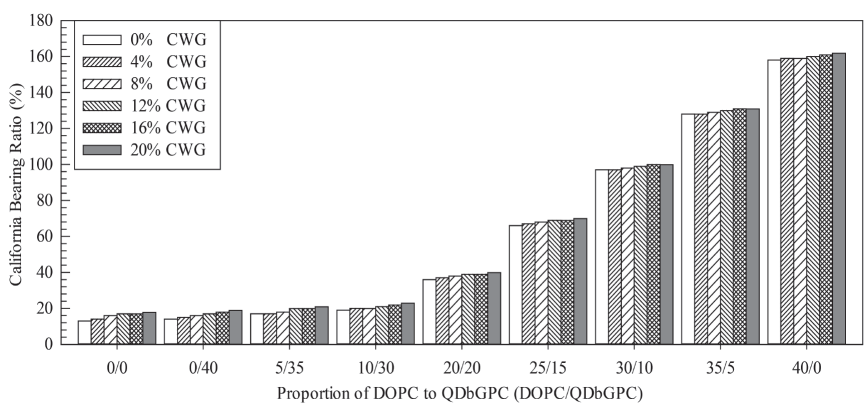

Fig. 8 California Bearing Ratio of DOPC+QDbGPC (\%) treated soil with CWG 8. ábra CWG tartalmú DOPC+QDbGPC-vel kezelt talaj kaliforniai teherbírási értéke

\section{Conclusions}

The test soil treated alternately with QDbGPC and OPC in the ratios of $0: 0,0: 40,5: 35,10: 30,15: 25,20: 20,25: 15,30: 10$, $35: 5$, and $40: 0 \%$ by weight respectively under the influence of $4 \%, 8 \%, 12 \%, 16 \%$ and $20 \%$ by weight crushed waste glasses over the cemented test soil was experimented in the lab and concluded as follows;

i. The preliminary test on the natural soil showed that the test soil was an expansive problem soil of highly plastic consistency unsuitable to be used as a pavement foundation material.

ii. The increase in the proportion of quarry dust based geopolymer cement and reduced ordinary Portland cement proportions improved the consistency, compaction and California bearing ratio characteristics of the soil

iii. The addition of crushed waste glasses also improved the tested properties of the soils of consistency and strength development. iv. The use of 40:0\% by weight of solid of the QDbGPC and DOPC respectively produced the highest improvement of the consistency and strength development characteristics of the treated soil.

v. This improvement has been achieved at zero release of $\mathrm{CO}_{2}$ into the atmosphere (at 40:0\% cementation) because the geopolymer cement is an ecofriendly geomaterials.

vi. Finally, the test exercise has generated a disposal mechanism for waste glasses and quarry dust as solid waste materials with an attendant improvement to soil reengineering for pavement foundation purposes in the composite blend of the silicate-based geopolymer cement.

\section{Funding}

This work was supported by the Ministry of Education and Training of Vietnam based on the decision No. 5652/QDBGDDT on December 28, 2018 with project number B2019MDA-08.

\section{References}

[1] Herve, P., et al. (2011): Desiccation cracking of soils, European Journal of Environmental and Civil Engineering, vol. 13: 7-8, pp. 869-888. https://doi.org/ 10.1080/19648189.2009.9693159

[2] Onyelowe, K. C. - Duc, Bui Van - Igboayaka, Clifford - Orji, Francis Henry Ugwuanyi (2018d): Rheology of mechanical properties of soft soil and stabilization protocols in the developing countries-Nigeria. Materials Science for Energy Technologies. https://doi.org/10.1016/j.mset.2018.10.001

[3] Abood, T. T. - Kasa, A. B. - Chik, Z. B. (2007): Stabilization of Silty Clay Soil Using Chloride Compounds, JEST, Malaysia, vol. 2, pp. 102-103

[4] Onyelowe, K. C. (2016a). Kaolin Stabilization of Olokoro Lateritic Soil Using Bone Ash as Admixture, International Journal of Constructive Research in Civil Engineering (IJCRCE) Volume 2, Issue 1, PP 1-9

[5] Onyelowe, K. C. (2016c): Axial Load and Compaction Behavior of Pozzolan Stabilized Lateritic Soil with Coconut Shell Husk Ash and Palm Kernel Shell Husk Ash Admixtures, International Journal of Innovative Studies in Sciences and Engineering Technology, Volume 2, Issue 2

[6] Onyelowe, K. C. (2016e): Effect of Coconut Shell Husk Ash and Palm Kernel Shell Husk Ash on the Grading and Consistency Behaviour of Pozzolan Stabilized Oboro Lateritic Soil, IISTE Journal of Civil and Environmental Research, Vol.8, No.3, pp. 55-63. (www.iiste.org, www. researchgate.net).

[7] Nigeria General Specification/Federal Ministry of Works and Housing (1997). Testing for the selection of soil for roads and bridges, Vol. II.

[8] Onyelowe, K. C. (2012b): Soil Stabilization Techniques and Procedures; A Clue for the Developing world-Nigeria, Global Journal of Engineering and Technology, GJET, India. Vol.5 (1) 65-69.

[9] Onyelowe, K. C. (2012c): Geochemistry of Soil Stabilization, ARPN Journal of Earth Sciences, Vol. 1, Issue 2, Pp. 32-35. 
[10] Edeh, Joseph Ejelikwu - Eberemu, Adrian Oshioname - Arigi, Abraham S. D. (2012): Reclaimed Asphalt Pavement Stabilized Using Crushed Concrete Waste as Highway Pavement Material, Advances in Civil Engineering Materials, 1 (1), 1-14, https://doi.org/10.1520/ACEM20120005.

[11] Onyelowe, K. C. - Duc Bui Van - Manh Nguyen Van (2018b): Swelling potential, shrinkage and durability of cemented and uncemented lateritic soils treated with CWC base geopolymer, International Journal of Geotechnical Engineering. https://doi.org/10.1080/19386362.2018.1462606

[12] Onyelowe, K. C. - Okafor, F. O. - Nwachukwu, D. G. (2012): Geophysical Use of Quarry Dust (as Admixture) as applied to Soil Stabilization and Modification-a review, ARPN Journal of Earth Sciences, PAKISTAN. 1(1).

[13] Onyelowe, K. C. (2017b): Nanosized palm bunch ash (NPBA) stabilisation of lateritic soil for construction purposes, International Journal of Geotechnical Engineering, TandF online, http://dx.doi.org/10.1080/19386362.2017.1322797

[14] Onyelowe, K. C. (2017c): Nanostructured Waste Paper Ash Stabilization of Lateritic Soils for Pavement Base Construction Purposes. Electronic Journal of Geotechnical Engineering, (22.09), pp 3633-3647. www.ejge.com

[15] Onyelowe, K. C. (2017d): Solid Wastes Management (SWM) in Nigeria and their Utilization in the Environmental Geotechnics as an Entrepreneurial Service Innovation (ESI) for Sustainable Development. Int J Waste Resour 7: 282. ISSN: 2252-5211.

[16] Onyelowe, K. C. (2017e): Nanosized Waste Paper Ash Stabilization of Lateritic Soil for Pavement Construction Purposes. Proceedings of the 2017 Annual Conference on Engineering for Self Reliance of the School of Engineering \& Engineering Technology (SEET), The Federal University of Technology, Akure, Nigeria, 11-13 July, 2017.

[17] Onyelowe, K. C. (2018): Kaolin soil and its stabilization potentials as nanostructured cementitious admixture for geotechnics purposes, International Journal of Pavement Research and Technology (in press), https://doi.org/10.1016/j.ijprt.2018.03.001.

[18] Onyelowe, K. C. - Ubachukwu, O. A. (2015): Stabilization of OlokoroUmuahia Lateritic Soil using Palm Bunch Ash (PBA) as Admixture, Umudike Journal of Engineering and Technology (UJET), Volume 1, Number 2, Pp. 67-77.

[19] Onyelowe, K. C. - Agunwamba, J. C. (2012b): Geotechnical Examination of the Geophysical Properties of Olokoro Lateritic Soil for Road Works, Nigeria Journal of Technology, NIJOTECH, Vol.31, No.3.

[20] Onyelowe, K. C. - Okafor, F. O. (2012): A Comparative Review of Soil Modification Mothods. ARPN Journal of Earth Sciences, PAKISTAN. 1(2).

[21] Onyelowe, K. C. - Okafor, F. O. (2013): Portland Cement/Quarry Dust Improvement of Olokoro Laterite for Road Base, World Journal of Engineering Science WJES, India. 1(4)133-143.

[22] Eberemu, Adrian O. - Amadi, Agapitus A. - Edeh, Joseph E. (2012):Diffusion of municipal waste contaminants in compacted lateritic soil treated with bagasse ash. Environmental Earth Sciences, https://doi.org/10.1007/s12665-012-2168-z

[23] Salahudeen, A. B. - Eberemu, A. O. - Osinubi, K. J. (2014): Assessment of Cement Kiln Dust-Treated Expansive Soil for the Construction of Flexible Pavements. Geotechnical and Geological Engineering, an International Journal, 32:923-931. https://doi.org/10.1007/s10706-014-9769-0

[24] Onyelowe, K. C. - Bui Van, D. (2018b): Predicting Subgrade Stiffness of Nanostructured Palm Bunch Ash Stabilized Lateritic Soil for Transport Geotechnics Purposes. Journal of GeoEngineering of Taiwan Geotechnical Society (in press). http://140.118.105.174/jge/index.php

[25] Onyelowe, K. C. - Bui Van, D. (2018c): Structural analysis of consolidation settlement behaviour of soil treated with alternative cementing materials for foundation purposes. Environmental Technology \& Innovation, Vol. 11, pp. 125-141. https://doi.org/10.1016/j.eti.2018.05.005

[26] Onyelowe, K. C. - Onuoha, I. C. - Ikpemo, O. C. - Okafor, F. O. Maduabuchi, M. N. - Kalu-Nchere, J. - Aguwa, P. (2017a): Nanostructured Clay (NC) and the Stabilization of Lateritic Soil for Construction Purposes. Electronic Journal of Geotechnical Engineering, (22.10), pp 41774196. www.ejge.com

[27] Onyelowe, K. C. - Ekwe, N. P. - Okafor, F. O. - Onuoha, I. C. - Maduabuchi, M. N. - Eze, G. T. (2017c): Investigation of the Stabilization Potentials of Nanosized-Waste Tyre Ash (NWTA) as Admixture with Lateritic Soil in
Nigeria. Umudike Journal of Engineering and Technology (UJET), Vol. 3 , No. 1, Pp. 26 - 35. www.ujetmouau.com

[28] Nikolov, A. - Rostovsky, I. - Nugteren, H. (2017): Geopolymer Materials Based on Natural Zeolite. Case Studies in Construction Materials. Vol. 6, Pp. 198-205. http://dx.doi.org/10.1016/j.cscm.2017.03.001

[29] Hamidi, R. M. - Man, Z. - Azizli, K. A. (2016): Concentration of $\mathrm{NaOH}$ and the Effect on the Properties of Fly Ash Based Geopolymer. $4^{\text {th }}$ International Conference of Process Engineering and Advanced Materials; Procedia Engineering, Vol. 148, Pp. 189-193.

http://dx.doi.org/10.1016/j.proeng.2016.06.568

[30] Bui Van, D. - Onyelowe, K. C. - Phi Van Dang - Dinh Phuc Hoang Nu Nguyen Thi - Wu, W. (2018): Strength Development of Lateritic Soil Stabilized by Local Nanostructured Ashes, Proceedings of China-Europe Conference On Geotechnical Engineering, SSGG, pp. 782-786, 2018. https://doi.org/10.1007/978-3-319-97112-4_175

[31] Davidovits, J. (2013): Geopolymer Cement a review. Institute Geopolymer, F-02100 Saint-Quentin, France. [online]

[32] Behzad, K. - Huat, B. B. K. (2008): Peat Soil Stabilization sing Ordinary Portland Cement, Polypropylene Fibers, and Air Curing Technique, EJGE, USA, Vol.13, pp. 1

[33] Onyelowe, K. C. - Onuoha, I. C (2016): Ordinary Portland Cement Stabilization of Amaoba-Umuahia Lateritic Soil using Snail Shell Ash, SSA as Admixture, International Journal of Innovative Studies in Sciences and Engineering Technology, Volume 2, Issue 1

[34] Onyelowe, K. C. - Ubachukwu, O. A. - Onuoha, I. C. - Ikpa, C - Umoren, P. (2016): Comparison between the Strength Characteristics of Pozzolan Stabilized Lateritic Soil of Coconut Shell Husk Ash and Palm Kernel Shell Husk Ash Admixtures, American Research Journal of Civil and Structural Engineering, Vol. 1, Issue 1, Pp. 1-8

[35] Škvára, F. - Jílek, T. - Kopecký, L. (2005): Geopolymer materials based on fly ash. Ceram.-Silik, 49(3), 195-204.

[36] Onyelowe, K. C. - Bui Van, D. - Dao-Phuc, L. - Onyelowe, F. - Ikpa, C. - Ezugwu, C. - Salahudeen, A. B. - Maduabuchi, M. - Obimba-Wogu, J. Ibe, K. - Ihenna, L. (2020): Evaluation of index and compaction properties of lateritic soils treated with quarry dust based geopolymer cement for subgrade purpose. Epitőanyag- Journal of Silicate Based and Composite Materials, Vol. 72, No. 1, pp. 12-15. https://doi.org/10.14382/epitoanyag-jsbcm.2020.2

[37] Srinivasan, K. - Sivakumar, A. (2013): Geopolymer binders: a need for future concrete construction. ISRN Polymer Science, volume 2013, Article ID 509185, 8 pages. DOI: http://dx.doi.org/10.1155/2013/509185

[38] Van Bui, D. - Onyelowe, K. (2018): Adsorbed complex and laboratory geotechnics of Quarry Dust (QD) stabilized lateritic soils. Environmental Technology \& Innovation, 10, 355-363. https://doi.org/10.1016/j.eti.2018.04.005

[39] Onyelowe, K. C. - Maduabuchi, M. N. (2017a): Palm Bunch Management and Disposal as Solid Waste and the Stabilization of Olokoro Lateritic Soil for Road Construction Purposes in Abia State, Nigeria. Int J Waste Resour Vol 7 Issue 2. https://doi.org/10.4172/2252-5211.1000279

[40] American Standard for Testing and Materials (ASTM) C618 (2014). Specification for Pozzolanas. ASTM International, Philadelphia, USA.

[41] TCVN 8859 (2011). Natural aggregates for road pavement layers. Vietnamese Specification for Material,s, Construction and Acceptance.

[42] Akbari, H. - Mensah-Biney, R. - Simms, J. (2015): Production of Geopolymer Binder from Coal Fly Ash to Make Cement-less Concrete. World of Coal Ash (WOCA) Conference in Nasvhille, TN-May 5-7. [online].

[43] Graber, E. R. - Fine, P. - Levy, G. J. (2006): Soil Stabilization in Semiarid and Arid Land Agriculture, Journal of Materials in Civil Engineering, ASCE, Vol.18. No.2, pp. 190-201

[44] Hasan, M. M. - Islam, M. R. - Tarefder, R. A. (2018): Characterization of subgrade soil mixed with recycled asphalt pavement. Journal of Traffic and Transportation Engineering, Vol. 5 (3), pp. 207-214. https://doi.org/10.1016/j.jtte.2017.03.007

[45] Little, D. N. - Males, E. H. - Prusinski, J. R. - Stewart, B. (2010): Cementitious Stabilization; Transportation in the New Millennium, Louisiana, USA, pp. 1-7. 
[46] Ai, C. - Li, Q. J. - Qiu, Y. (2015). Testing and assessing the performance of a new warm mix asphalt with SMC. Journal of Traffic and Transportation Engineering, Vol. 2 (6), pp. 399-405. http://dx.doi.org/10.1016/j.jtte.2015.10.002

[47] Abdel-Gawwadm, H. A. - Abo-El-Enein, S. A. (2016): A Novel Method to Produce Dry Polymer Cement Powder. HBRC Journal. Vol. 12, Pp. 13-24. http://dx.doi.org/10.1016/j.hbrcj.2014.06.0018

[48] BS 1377 - 2, 3, (1990). Methods of Testing Soils for Civil Engineering Purposes, British Standard Institute, London.

[49] BS 1924, (1990). Methods of Tests for Stabilized Soil, British Standard Institute, London.

[50] TCVN 9504 (2012). Specification for construction and acceptance of water bound macadam layer. Vietnmese Standard Code for Concrete Materials.

[51] AASHTO (1993): Guide for Design of Pavement Structures. American Association of State Highway and Transportation Officials (AASHTO), Washington DC.

[52] AASHTO (2005): Standard Specification for Transportation Materials and Methods of Sampling and Testing, Part II Methods of Sampling and Testing $25^{\text {th }}$ Edition. American Association of State Highway and Transportation Officials, Washington DC.

[53] AASHTO T 190-09 (2014): Standard method of test for resistance R-value and expansion pressure of compacted soils. American Association of State Highway and Transportation Officials, Washington DC.

[54] AASHTO T 307 (2014): Standard method of test for determining the resilient modulus of soils and aggregate materials. American Association of State Highway and Transportation Officials, Washington DC.

[55] TCVN 8858 (2011): Cement treated aggregates bases for road pavement. Vietnamese Specification for Construction and Acceptance.

[56] Wei, H. - Dong-yan, L. - Bao-yun, Z. - Yan-bo, F. - Yu-chao, X (2014): Study on the Rheological Properties and Constitutive Model of Shenzhen Mucky Soft Soil. Journal of Engineering Science and Technology Review 7 (3), pp. $55-61$
[57] Zhu, G. - Zhu, L. - Yu, C. (2017): Rheology properties of soils; a review. International Symposium on Resource Exploration and Environmental Science, Earth and Environmental Science 64, pp. 1-8. https://doi.org/10.1088/1755-1315/64/1/012011.

[58] Srivastava, V. - Atul, Imam - Mehta, A. - Satyendranath, P. K. - Tripathi, M. K. (2018): Supplementary Cementitious Materials in Construction - An Attempt to Reduce $\mathrm{CO}_{2}$ Emission. Journal of Environmental Nanotechnology, Volume 7, No.2, pp. 31-36. https://doi.org/10.13074/jent.2018.06.182306

[59] Smith, G. N. - Smith, I. G. N. (1998): Elements of Soil Mechanics, 7th Edition, Blackwell Science, Inc., USA.

[60] Gidigasu, M. D. - Dogbey, J. L. K. (1980): Geotechnical Characterization of Laterized Decomposed Rocks for Pavement Construction in Dry Sub-Humid Environment". $6^{\text {th }}$ South East Asian Conference on Soil Engineering, Taipei, 1, 493-506.Garg, S.K. (2005). Soil Mechanics and Foundation Engineering, 6th Edition, Kharna Publishers, Delhi

[61] Onyelowe, K. C. - Bui Van, D. (2018a): Durability of nanostructured biomasses ash (NBA) stabilized expansive soils for pavement foundation, International Journal of Geotechnical Engineering, https://doi.org/10.1080/19386362.2017.1422909

$\underline{\text { Ref.: }}$

Bui Van, Duc - Onyelowe, Kennedy Chibuzor - Onyia, Michael - Xuan, Man Nguyen - Phuc, Lam Dao - Ikpa, Chidozie Yubonchit, Somjai - Eberemu, Adrian - Osinubi, Kolawole Salahudeen, A. Bunyamin - Amadi, Agapitus - Maduabuchi, Michael - Obimba-Wogu, Jesuborn - Onuoha, Ifeanyichukwu Saing, Zubair: Strength and consistency behaviour of replacement of cement with silicate-based geopolymer cement modified soft soil treated with crushed waste glasses for pavement underlain Építőanyag - Journal of Silicate Based and Composite Materials, Vol. 72, No. 6 (2020), 186-197. p. https://doi.org/10.14382/epitoanyag-jsbcm.2020.31

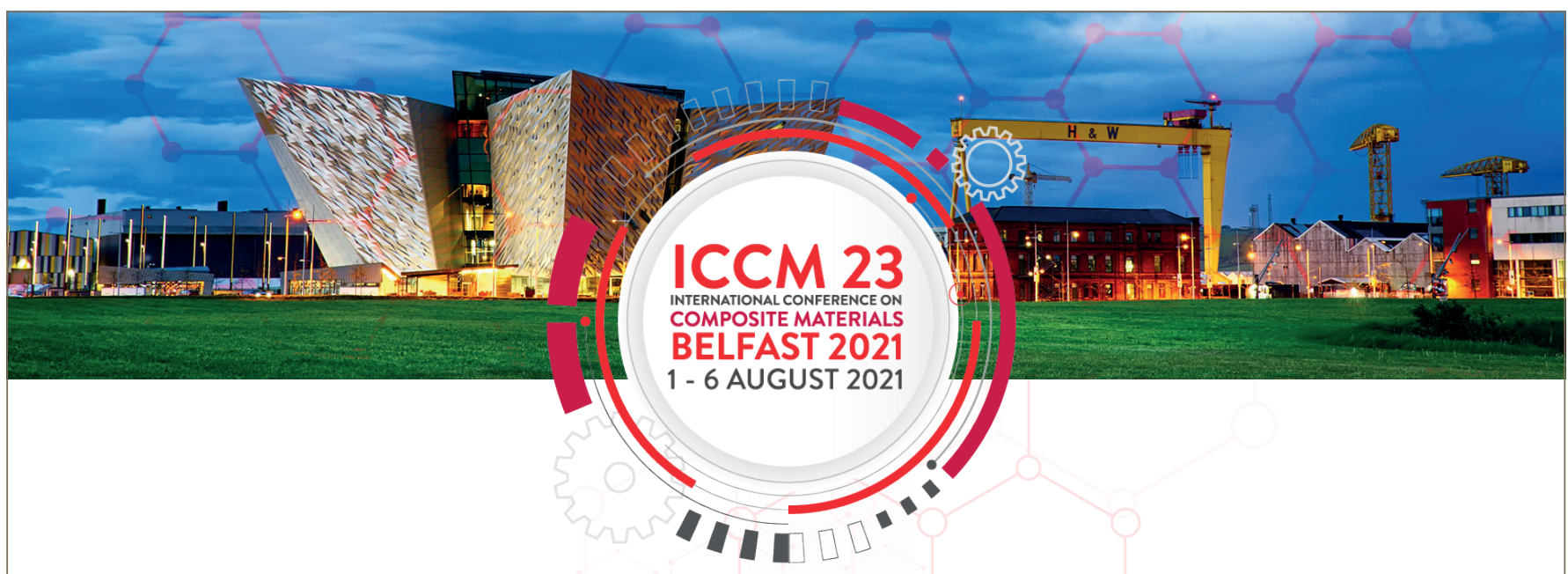

The 23rd International Conference on Composites Materials (ICCM 23) will be held in Belfast, Northern Ireland, from the 1st to 6th of August 2021. ICCM is the premier international conference in the field of composite materials and was first held in 1975 in the cities of Geneva and Boston. Since that time the conference has been held biennially in North American, European, Asian, Oceanic, and African cities.

ICCM 23 will attract the leading researchers and practitioners, to report and exchange ideas on the latest developments in the advancement and exploitation of a wide range of composites materials and structures. The general themes of material development, testing, modelling, manufacturing and design will encompass a breadth of topics which will provide a comprehensive global snap-shot of the state-of-the-art.

Plenary and keynote lectures from pre-eminent leaders in the field are planned, along with oral and poster presentations from an expected large delegation coming together in Belfast from all corners of the world. A number of site visits and an entertaining social programme are also planned.

\section{iccm23.org}

